\title{
Analysing Complaints and Grievances as a Quality Improvement Tool in Universities
}

\author{
EVELYN CHIYEVO Garwe \\ Zimbabwe Council for Higher Education, Zimbabwe \\ E-mail: garweec@gmail.com
}

Received: March 22, 2015 Accepted: April 14, 2015 Published: May 7, 2015

doi:10.5296/v3i2.7288 URL: http://dx.doi.org/10.5296/v3i2.7288

\begin{abstract}
Complaints and grievances are useful quality assurance tools in the identification of shortcomings which impede quality of higher educational delivery. However, there is a dearth of studies that analysed complaints by stakeholders in the higher education sector in Zimbabwe. This study used the documentary research method described by Yin (1994) to examine the origin, frequency and types of complaints lodged with the higher education quality assurance agency by 74 academic staff members, 60 students and 45 from other higher education stakeholders. Records of all unsolicited complaints received through written, electronic, verbal or telephonic means from 2011 and 2014 were reviewed, analysed and categorised. The results revealed an upward trend in the number of complaints from 2011 to 2014 . Out of the 179 complaints received over the study period, $45 \%$ were from academic staff members, $38 \%$ from students, $7 \%$ from employers, $6 \%$ from the public, $1 \%$ from media houses and $3 \%$ were anonymous. The complaints from academics and students came from 12 of the 15 registered universities in Zimbabwe. Fifty-eight percent of the complaints (excluding the anonymous complaints) were from males and $42 \%$ came from females. The complaints related to high workloads $(93 \%)$, large class sizes $(60 \%)$, high administration expenses relative to teaching and research (49\%), favouritism and corruption (44\%) and poor quality of graduates (11\%). The study informs higher education institutions on areas they need to concentrate on in order to improve quality and recommends institutions to develop and implement effective internal grievance management systems.
\end{abstract}

Keywords: complaints, quality, higher education, academics, students 


\section{Introduction}

The government of Zimbabwe is committed to the maintenance of a competitive higher education sector which produces productive and enterprising graduates and carries out high quality research and innovation. This commitment is evidenced by the establishment of the Zimbabwe Council for Higher Education (ZIMCHE), a national quality assurance watchdog mandated to register and accredit higher education institutions as well as overseeing the maintenance of high educational standards in the higher education sector (Bukaliya \& Rupande, 2013). ZIMCHE works hand in hand with the Ministry of Higher and Tertiary Education, Science and Technology Development, higher education institutions, employers, professional bodies and all other stakeholders to continuously improve quality. This close collaboration has resulted in increased access, through expansion and establishment of public and private institutions as well as introducing new disciplines and modes of delivery whilst keeping an eye on quality (Garwe, 2013). In all these developments, ZIMCHE assists institutions in applying agreed quality standards in higher education. In addition to its other roles, ZIMCHE receives feedback in the form of complaints and grievances from stakeholders. The analysis and dissemination of these issues of concern is critical in promoting quality in higher education (Katiliūtė \& Kazlauskiene, 2010). This study analyses the origin, frequency and types of complaints lodged with ZIMCHE by staff, students and other higher education stakeholders. The findings will assist in identifying issues that need improvement and attention.

\subsection{Putting Complaints and Grievances in Context}

It is an agreed fact that in order to improve quality in higher education, an effective complaint management system is essential (Latif, Ramli, \& Fard, 2010). Boshoff (2007) refer to complaints as unavoidable consequences of all service delivery activities or as outcomes of client dissatisfaction. Although complaints on issues that affect the quality of higher education are normally viewed negatively, they are actually essential quality assurance tools that assist in identifying problems that are usually significant and deserve the attention (Landon, 1980). Complaints are critical sources of information necessary for quality improvement (Reader, Gillespie, \& Roberts, 2014). Studies in commerce have shown a mere four percent of dis-satisfied clients bother to complain, the majority will simply stop doing business with the organisation. In addition, satisfied clients will tell only one person about good service whilst dissatisfied clients will alert at least 10 colleagues about poor service (Barlow et al., 2009; Bierch, 2012; Lee, 2011). Some clients will formally lodge their complaints to regulatory organisations outside the service institution or they may take legal action against the service institution (Day, 2007). This shows the importance of taking complaints seriously. Whilst both compliments and complaints provide critical information to inform higher education institutions on areas requiring improvement, this study focuses only on complaints and grievances. Despite the importance of complaints in quality assurance, there is a dearth of studies that analysed complaints by stakeholders in the higher education sector in Zimbabwe. This study attempts to bridge this knowledge gap.

Barlow, Moller, and Hsier (2009) provide a simple definition of a complaint: "a statement about expectations that have not been met." Accordingly, in the higher education context, a 
complaint can be a formal or informal claim or expression of dissatisfaction with improper, unfair, or discriminatory treatment regarding anything for example, staff, procedures, fees, or teaching and learning conditions (Salamon, 2000). Felstiner, Abel, and Sarat (1981) assert that a complaint may, but need not, constitute a grievance. A grievance is an allegation, a violation or a breach of written policies, procedures and regulations or agreed expectations lodged with the aim of eliciting change (D'Cruz, 1999). This study adopts a single definition for complaints and grievances suggested by Rose (2004) to refer to a whole range of dissatisfactions and discontents (legitimate or ridiculous) that people encounter in higher education institutions.

Jackson, Fleming, Kamvounias, and Varnham (2009) reported that university students usually make complains about a lecturer, course or grade that does not measure up to their expectations, or are discontented because they were not granted special consideration or that they were unfairly disadvantaged by a particular process. Similarly, university staff members often feel aggrieved because they perceive that their freedom has been compromised due to unfair practices in the working environment. In such a situation, Tinto (1993) avers that aggrieved staff and students fail to fit in and identify with the culture of the university and some end up leaving the institution whilst some resort to internal and external grievance processes and legal mechanisms.

\subsection{Complaint and Grievance Management in Zimbabwe}

In Zimbabwe, the higher education complaint management system involves lodging a grievance through internal complaints and appeals processes before approaching the Ministry of Higher and Tertiary Education, Science and Technology Development and the higher education quality assurance agency, ZIMCHE. Stakeholders who are not satisfied with service, teaching and learning issues or any other matter related to the quality of higher education and they believe that someone is breaching agreed requirements are free to raise their grievances through internal complaints and appeals processes. However, very often stakeholders who are not happy with the outcomes or lack of action by their institution often submit their complaints to the ZIMCHE. The complaints are submitted in various forms including written, electronic, verbal or telephonic. Whilst ZIMCHE discourages complaints by unidentified sources, some are still submitted anonymously. ZIMCHE takes all complaints seriously and whilst the complainants are not responded to directly, conceited efforts are made to investigate the issues and work hand in hand with higher education institutions and other stakeholders to resolve the problems. It is important to note that effective complaint management should not be 28ocused solely on lowering the quantity of complaints and grievances, but on converting the information generated to good use.

\section{Methodology}

The study examined all the complaints and grievances received by ZIMCHE through written, electronic, verbal and telephonic means from 2011 and 2014. The study explored the research questions: "What are the origins (sources), frequency and types of complaints and grievances lodged with the higher education quality assurance agency (ZIMCHE)?" Yin (1994) suggests that such questions ought to be exploited through research strategies such as explanatory case 
studies or histories. Accordingly, the document research method was found appropriate for the current study because it makes it possible to collect and analyse qualitative and quantitative information on extensive historical data stored in the documents. Despite the importance of this method, it is most frequently challenged by some researchers who are either not familiar or are sceptical about the effectiveness of the sole use of the documentary research method (Yin, 2003). Notwithstanding the fact that some researchers are either not familiar or are sceptical about the effectiveness of the sole use of the documentary research method, many researchers have proved beyond doubt that even as a stand-alone method, it is a respected, tried and tested research methodology which should be exploited by researchers with full confidence (Ahmed, 2010; Hakim 1982; Mogalakwe, 2006).

The documentary research method refers to the identification and analysis of documents that contain information pertaining to the phenomenon under study (Bailey, 1994). This method is useful in examining and categorising primary and secondary data (Payne \& Payne, 2004). Bailey (1994) distinguished between primary and secondary documents. The former are accounts created by eye-witness to the matter under study whilst the latter are accounts from people who did not experience the issues or events first-hand. Scott (1990) defines a document simply as a 'written text.' Other researchers add that documents can be in the form of files, diaries, statistics, reports, memoranda; records of proceedings, complaints, pronouncements, requests, images and other written, visual and pictorial forms (Bailey 1994; Denscombe, 1998; Polit \& Hungler 1991; Silverman, 1993).

The documentary research method involves four key steps namely: document search, reading, analysis and write-up (Walsh, 2014). The analysis step involves establishing the reliability and authenticity of the documents and comprises of quantitative (McNally, 2013), interpretive (Cohen, Manion, \& Morrison, 2011) and critical (Kincheloe \& McLaren, 2002) approaches. Robson (2011) adds that during the analysis stage, it is critical to identify the context and to establish the source as well as the purpose of the document. The key advantages of using documentary analysis are: the easy access to information; removal of researcher bias; ability to tracking trends over time; ability to obtain detailed and spontaneous data for example feelings, actions and confessions and low study costs (Ahmed, 2010). In support of this rigorous research method, Scott (1990) provides an in-depth explanation of the nitty-gritties of this methodology.

In this study documentary analysis covers all complaints and grievances received by ZIMCHE for four years commencing 2011 through to 2014. The analysis was carried out by the researcher with permission from ZIMCHE. ZIMCHE maintains a central record of all unsolicited complaints received through written, electronic, verbal or telephonic means from universities and other higher education stakeholders. The study adopted the four steps as guided by Walsh (2014) namely: identifying, reading and analysing the documents. In order to ascertain the trustworthiness of data with respect to issues of validity, reliability credibility, dependability and transferability, authenticity, the researcher took time to critically reflect on the evidence provided by the informants' complaints, before making judgements, realistic arguments and explanations as suggested by Mason (2002). Accordlingly, out of 253 complaints recorded in the grievance register, 179 were judged by the researcher as 


\section{Macrothink Institute ${ }^{\text {TM }}$}

trustworthy and these were included in the final analysis. The complaints that were excluded in the final analysis were mostly of verbal or telephonic origin and these lacked enough information regarding the details (for example gender and institution) of the informant, the nature of the complaint as well as the extend of the problem.

\section{Findings}

\subsection{Total number of Complaints over 4 Years from 2011 to 2014}

Although 253 cases were recorded in the complaints register, 179 complaints and grievances were included in the final analysis as reported under Section 2. The complaints from academics and students came from 12 of the 15 registered universities in Zimbabwe.

Figure 1 shows the trend in the number of complaints and grievances over the 4 year period.

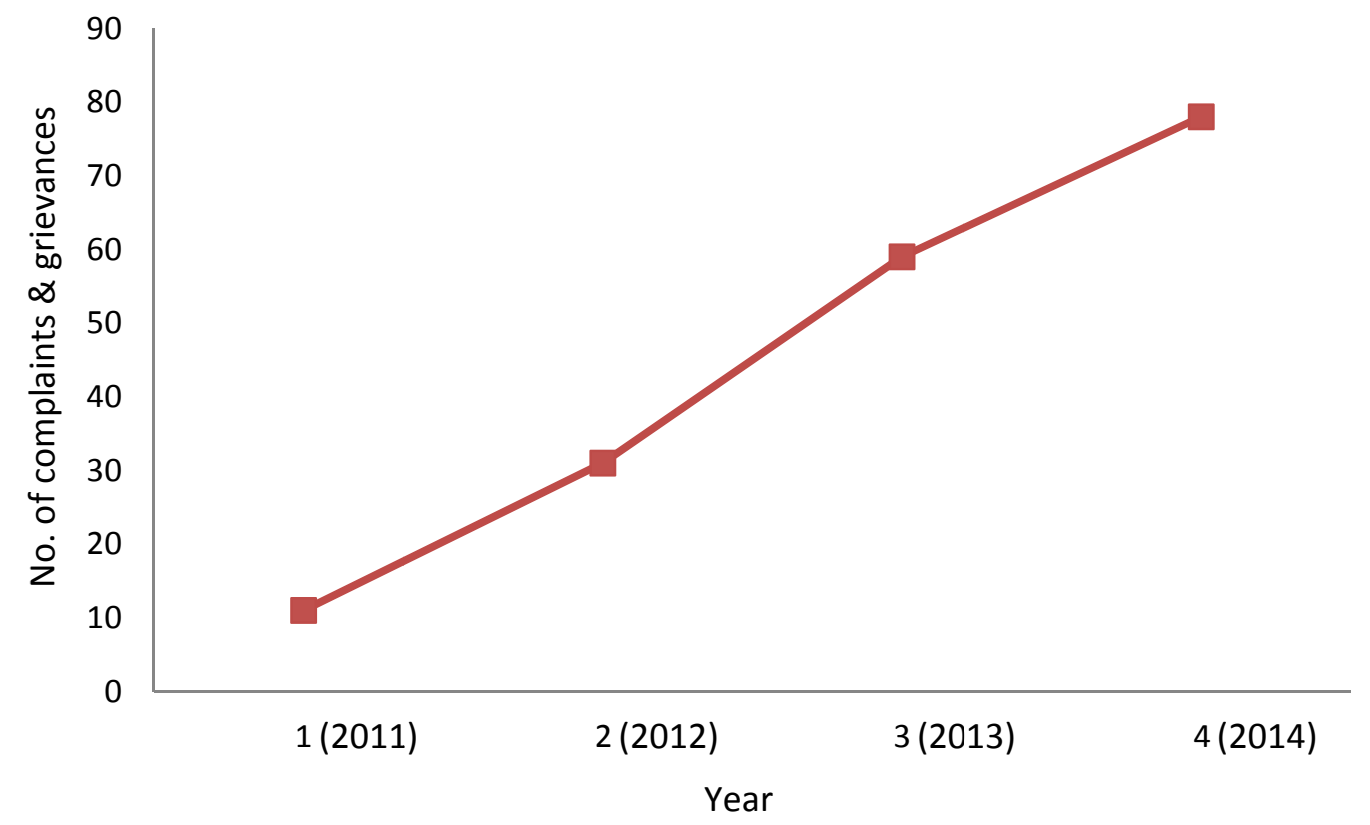

Figure 1. Trend in the number of complaints and grievances (2011-2014)

Figure 1 shows that the number of complaints and grievances increased almost exponentially through the 4 year period. These increased from 11, 31, 59 and 78 in 2011, 2012, 2013 and 2014 respectively.

\subsection{Source of Complaints}

Figure 2 shows the number of complaints categorized by the source of the complaints whilst Table 1 shows the proportion of complaints that were registered in each category. 


\section{Macrothink

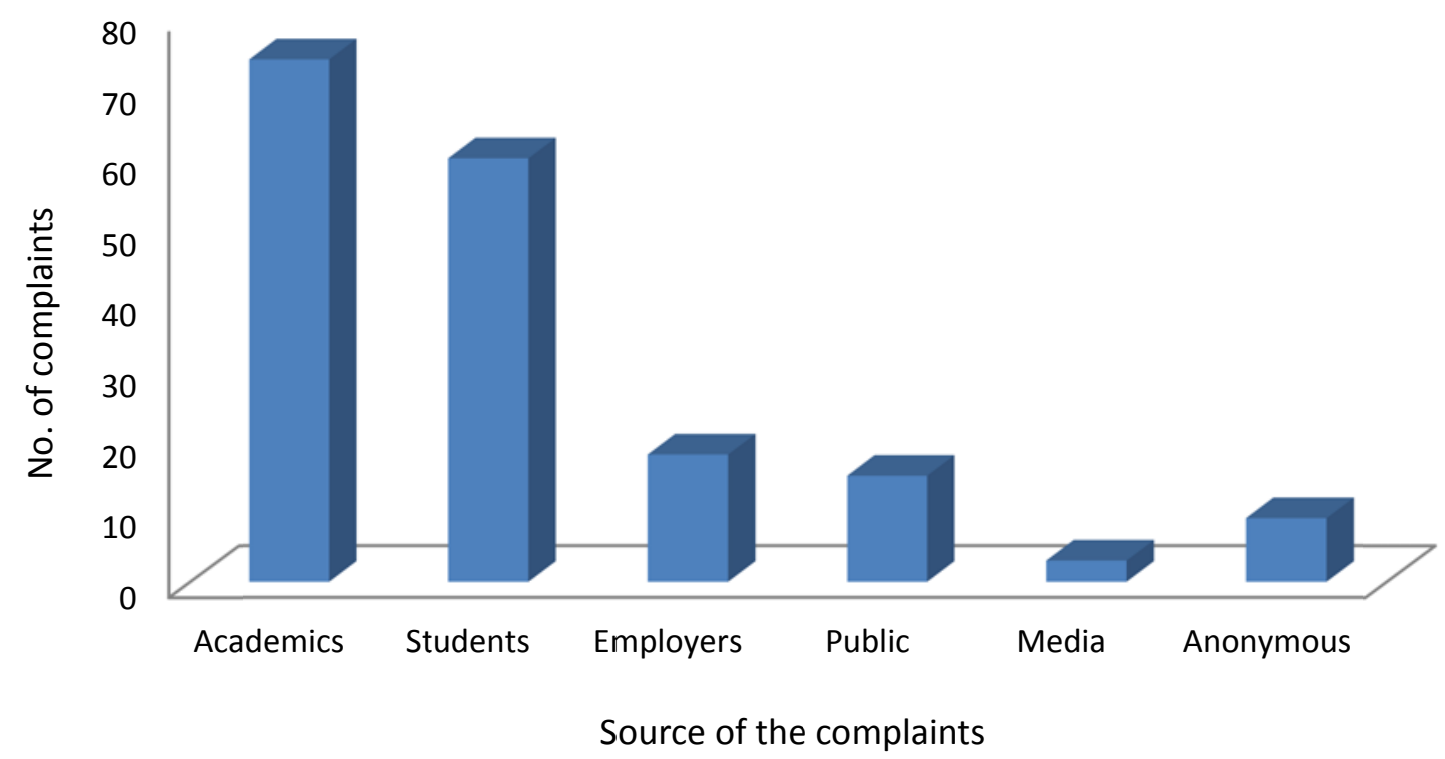

Figure 2. Number of complaints categorized by the source of the complaints

It can be seen from Figure 2 that most of the complaints ( 74 and 60) came from academic staff and students respectively.

Table 1. Proportion of complaints that were registered in each category

\begin{tabular}{lccc}
\hline Category & Male (\%) & Female (\%) & Total (\%) \\
\hline Academic staff & 55 & 45 & 41 \\
Students & 58 & 42 & 34 \\
Employers & 67 & 33 & 10 \\
Public & 53 & 47 & 8 \\
Media houses & 100 & 0 & 2 \\
Anonymous & 56 & 44 & 5 \\
Total & 58 & 42 & 100 \\
\hline
\end{tabular}

Table 1 shows that overall, most complaints (58\%) came from males although this varied from category to category. Table 1 also shows that the source of complaints and grievances on higher education issues were from academics (41\%), students $(34 \%)$, employers $(10 \%)$, members of the public $(8 \%)$, media houses $(2 \%)$ and from anonymous sources $(5 \%)$. 


\subsection{Issues Complained about}

Table 2 shows the categorisation of the types of complaints and grievances received.

Table 2. Categorisation of the types of complaints and grievances received (2011-2014)

\begin{tabular}{lll}
\hline Category & Number & Percentage \\
\hline High workloads & 60 & 34 \\
Large class sizes & 49 & 27 \\
Poor quality of graduates/interns & 23 & 13 \\
Inappropriately qualified staff & 19 & 11 \\
High administration expenses & 15 & 8 \\
Favouritism and corruption & 13 & 7 \\
\hline
\end{tabular}

Table 2 shows that the largest complaint was that of high workloads (34\%) involving mostly teaching and administrative assignments. This concern applied only to academics. Academics complained that they were essentially teaching three times the normal load. This was because during the day they would take students attending conventional studies (between 0800 hours and 1700 hours) and block release students who normally come for intensive learning during holidays for periods of up to 5 weeks per semester. In addition, they would also take part-time students who come for evening classes from 1730 hours to 2030 hours as well as during weekends. These three groups of students normally study for the same programmes and therefore the contact hours are similar. Chairpersons of departments, Programme Coordinators and Deans complained that in addition to teaching, they also had to attend to meetings a horde of other administrative duties. This had a negative impact on the quantity and quality of research they were carrying out due to time limitations.

Large class sizes constituted $27 \%$ of the complaints. This concern came mostly from the students but some of the academics also raised the same concern. Large class sizes meant that some students could not get attention of the lecturers. The resources were inadequate to the extent that some students failed to get simple things like desks and chairs. Some classrooms did not have public address systems, making it impossible for the students to follow the lectures. From the lecturers' point of view large class sizes of at times 600 and above meant that the lecturers had to spend a lot of time marking and preparing adequate materials for the class.

The third major concern was that of poor quality graduates or students on attachment $(13 \%)$ that were purportedly being churned out by some universities. This issue was raised by employers, the public and the media. Some of the graduates did not have the requisite knowledge and skills required by industry. Employers complained mostly about graduates who were high flyers on paper such that they seemed attractive as candidlates for the limited jobs. However, upon engagement, these graduates did not show their worth. Employers complained that the quality assurance process championed by ZIMCHE should be able to 
improve on the quality of graduates across all universities. They went on to indicate that students on attachment from similar programmes in different universities did not perform at par. Some universities fared much better than others.

Inappropriately qualified staff featured in $11 \%$ of the complaints. Although the major source of this complaint was from students, it was interesting to note that some academics also complained about their colleagues who were destroying the good name of the profession. Some lecturers were said to only come to class to boast about their achievements or their families, leaving very little time for serious business. Other complaints were to the effect that lecturers with qualifications in a different field were made to teach any subject, the argument being that they met the minimum requirements and hence they were eligible to teach. After all, university education was about opening up people's brains and preparing them for any eventuality, they argued.

Eight percent of the complaints mostly coming from academics were to the effect that most university funds were deployed for administrative and travel expenses compared to those associated directly with teaching and learning as well as for research purposes. Complains chronicled how university management were giving themselves huge perks and how administrative posts and the concomitant support staff continued to increase in number at the expense of the actual core business. Similar studies revealed that the scenario were spending on administrative issues has overtaken the expenditure for teaching and learning as started as far back as 1930 (Bergmann, 1991). This was different from other sectors of the economy where organisations are streamlining their non-core functions by merging, sharing resources and services as well as employing other ways of reducing administrative overheads.

Favouritism and corruption accounted for $7 \%$ of the complaints. These complaints came from both students and academics. Academics submitted the complaints and grievances either as groups or individuals. Those who submitted as groups complained mainly of corruption in allocation of financial resources. Some lecturers had no problems having their travel or research trips approved whereas others had to struggle. Jain, Kusum and Shelly (2013) also found that into the Indian education system was fraught with issues of corruption due to the desire to make money at the expense of human development. Meet \& Nayaran (2014) argue that education has the potential to act as a tool to improve good governance and to reduce corruption only if the education environment is corruption-free.

\section{Discussion and Analysis}

The objective of this study was to analyse the origin, frequency and types of complaints lodged with ZIMCHE by staff, students and other higher education stakeholders with the aim of identifying issues that need improvement and attention in the higher education sector. Although it was established that he complaints from academics and students came from 12 of the 15 registered universities in Zimbabwe, it was not clear why the other three universities did not register a single complaint. This may probably point to the existence of effective complaint management systems in these universities. However further studies need to be done to elucidate on this state of affairs. 


\subsection{Trend Analysis}

The findings show an upward trend in the number of complaints and grievances received over the four year period. This can be attributed to the fact that people are becoming more aware of the role that ZIMCHE plays in quality assurance. This upward trend agrees with the findings by Olliffe and Stuhmcke (2007) who reported increasing numbers and complexity of complaints coming from institutions of higher education. They attribute this to the increase in university enrolments and argue that the higher the student numbers, the more the number of complaints concerning decision making by management. Moreover, the higher the number of students, the higher the number of academics who also will be having their own grievances arising from the general 'feeling' that their academic freedom is at stake (Field \& Barnes, 2003).

The other reason that can contribute to the increase in complaints is the increase in commercialisation of higher education. The introduction and growth of fee-paying students builds high expectations in the students who view themselves as 'customers,' resulting in them having a high propensity to complain. In Zimbabwe the concept of commercialisation of higher education does not only apply to private institutions but also relate to public institutions. The decline in funding provided by the government has led public institutions to introduce demand driven courses and increase enrollments substantially without concomitant improvement in resources and facilities. This leads to a mismatch between student numbers and available teaching and learning resources, a phenomenon referred to as 'massification' (Mohamedbhai, 2008). For example, there will be an increase in student/teacher ratio resulting in compromising individual teacher/student interaction. Kasozi (2006) and Mamdani (2007), attribute the duplication and fragmentation of degree programmes to the effects of commercialisation of higher education. The researchers argue that whilst students get attracted to programmes by name, the early specialisation negatively impacts on knowledge and skills thereby affecting chances of employability.

The increase in complaints and grievances points to the fact that maybe higher education institutions lack acceptable and friendly internal policies and procedures to handle complaints and grievances. However, some of the complaints (from the public, media and employers) are outside the control these institutions. Olliffe and Stuhmcke (2007) added that those who are involved in investigating complaints and grievances in institutions might not have any formal training and they also handle grievances in addition to their normal jobs thereby raising issues of quality and timeliness of grievance handling. It is important to note that when stakeholders perceive that they are not getting sufficient joy with internal grievance systems, they may publicly expose their experience, thereby negatively impacting on the institution's reputation.

On a positive note, researchers aver that the higher the quantum of complains and grievances, the higher the prospects of improving the system (Noe, Hollenbeck, Gerhart, \& Wright, 2003). These researchers aver that lower rates of complaints and grievances reflect reluctance to lodge a complaint due to fear of victimisation or lack of faith in the grievance procedures. Market research concedes that only four percent of dissatisfied clients will actually complain whilst the majority will simply stop doing business with the organisation (Barlow, Moller, \& 
Hsier, 2009; Bierch, 2012; Lee, 2011; Plymire 1991). This arises from the fact that the "word of mouth" impacts negatively on the reputation of the organisation (Reichheld \& Sasser 1990).

\subsection{Sources and Types of Complaints and Grievances}

The largest source of complaints and grievances was from academics (41\%). These complained mainly of high workloads, large class sizes and poor prioritisation of limited funds resulting in most funding being allocated to administrative and travel expenses at the detriment of the core business of teaching and learning as well as research. The combined effect of these complaints is that academics end up stressed and fail to deliver to expectations. In addition, the academics do not find time or funding to carry out research or to publish hence jeopardising their chances of promotion and admission into doctoral studies. This is because the quantum and quality of research determines whether one is promoted or admitted into doctoral studies.

The high incidence of dissatisfaction amongst academics in Zimbabwe agree with recent literature which found overwhelming evidence substantiating that the academic profession is extremely stressful (Barkhuizen, \& Rothmann, 2008; Kinman, 2001) In fact, Barkhuizen and Rothmann (2008) described higher education institutions as "stress factories." The causes of stress that were cited included high workloads, limitations of time, failure to meet promotion criteria, lack of recognition, insufficient remuneration, limited resources, poor interactions with students and peers, high self-expectations, job insecurity and inequality in the system (Abouserie, 1996; Doyle \& Hind, 1998; Hind \& Doyle, 1996; Kinman, 1998; Tytherleigh, Webb, Cooper, \& Ricketts, 2005). Barkhuizen and Rothmann (2008) contend that dissatisfaction leads to poor quality of performance and lower productivity resulting from lack of commitment, absenteeism, and a high turnover of staff.

The finding that academics are dissatisfied in their jobs are contrary to the traditional belief that academics enjoy tenured jobs, flexible workloads, huge 'perks' inclusive of international trips to pursue studies or to attend conferences as well as freedom to carry out research (Fisher, 1994; Gillespie, Walsch, Winefield, Dua, \& Stough, 2001).

Complaints and grievances from students (34\%) were about large class sizes, inappropriately qualified staff and favoritism and corruption. ZIMCHE takes the issues affecting the quality of teaching and learning very seriously and endevours to visit each institution were students register complaints. In fact, ZIMCHE through its Higher Education Committee on Students Affairs proactively carries out regular surveys to check on issues affecting the quality of educational provision from the students' and staff points of view (ZIMCHE, 2013).

Five percent of the complaints were from anonymous sources. Although ZIMCHE does not encourage anonymous complaints, depending on the nature of the issue, ZIMCHE will still attempt to investigate the issue. 


\section{Conclusion}

Providing a conducive environment for quality teaching, learning and research is the primary responsibility of universities. In addition, universities must satisfy the needs and expectations of other key stakeholders. The present study found that the number of complaints and grievances submitted to ZIMCHE had risen exponentially from 2011 to 2014 . Whilst it is imperative that these complaints be attended to immediately, the increase in complaints and grievances per se does not constitute a problem but it affords an opportunity for quality improvement. The complaints originated from academics, students, employers, members of the public, media houses and from anonymous sources in that order. The complaints from academics and students came from 12 of the 15 registered universities in Zimbabwe. The complaints were categorized as high workloads, large class sizes, poor quality of graduates/interns, inappropriately qualified staff, high administration expenses and favouritism and corruption. In line with Latif et al. (2010) and recognising the importance of complains as pointers to areas that need improvement, the study recommends that higher education institutions pay more attention to addressing the complains raised in this study. Latif et al. (2010) aver that if complainants feel that their concerns are not taken seriously or ignored, they can expose them publicly thus negatively affecting the institution's reputation.

Although the study design afforded a unique opportunity to analyse complaints and grievances in higher education, the effectiveness of the complaint management of individual universities was not explored. The study recommends that institutions develop and implement effective complaint management systems. However, further research is needed to understand whether the absence of complaints from three of the Zimbabwean universities means that these institutions have put in place robust complaint management systems.

\section{References}

Abouserie, R. (1996). Stress, coping strategies and job satisfaction in university academic staff. Educational Psychology, 16, 49-56. http://dx.doi.org/10.1080/0144341960160104

Ahmed, J. U. (2010). Documentary Research Method: New Dimensions. Industrial Journal of Management \& Social Sciences, 4(1), 1-14.

Bailey, K. D. (1994). Methods of Social Research. New York: The Free Press.

Barkhuizen, N., \& Rothmann, S. (2008). Occupational stress of academic staff in South African higher education institutions. South African Journal of Psychology, 38(2), 321-336. http://dx.doi.org/10.1177/008124630803800205

Barlow, J., Moller, C., \& Hsier, T. (2009). Complaint Is a Gift: Recovering Customer Loyalty When Things Go Wrong (p. 287, 2nd ed.). San Francisco: Berrett-Koehler Publishers.

Bergmann, B. R. (1991). Bloated administration, blighted campuses. Academe, Bulletin of the American Association of University Professors, 77(6), 12-16.

Bierch, E. (2012). Developing talent for organisational results: Training tools from the best in the field. Pfeiffer ${ }^{\circledR}$. 
Boshoff, C. R. (2007). An experimental study of service recovery options. International Journal of Service Industry Management, 8(2), 110-130. http://dx.doi.org/10.1108/09564239710166245

Bukaliya, R., \& Rupande, G. (2013). Challenges faced by ODL Institutions in meeting Quality Standards Set by University Regulatory Authorities: A Case for the Zimbabwe Open University. International Journal of Advanced Research, 1(4), 422-429.

Cohen, L., Manion, L., \& Morrison, K. (2011). Research methods in education (7th ed.). New York: Routledge.

D’Cruz, M. N. (1999). A Practical Guide to Grievance Procedure, Misconduct and Domestic Inquiry. Kuala Lumpur: Leeds Publication.

Day, R. L., \& Ash, S. B. (2007). Consumer response to dissatisfaction with durable products, Advances in Consumer Research, 6, 438-444.

Denscombe, M. (1998). The Good Research Guide for small-scale social research projects. Buckingham: Open University Press.

Doyle, C., \& Hind, P. (1998). Occupational stress, burnout and job status in female academics. Gender, Work and Organisations, 5, 67-82. http://dx.doi.org/10.1111/1468-0432.00047

Felstiner, W. L. F., Abel, R. L., \& Sarat, A. (1981). The Emergence and Transformation of Disputes: Naming, Blaming, and Claiming. Law and Society Review, 15, 631-644. http://dx.doi.org/10.2307/3053505

Field, R., \& Barnes, M. (2003). University ombuds: Issues for fair and equitable complaints resolution. Australasian Dispute Resolution Journal, 14, 198.

Fisher, S. (1994). Stress in academic life: The mental assembly line. Buckingham, UK: Open University Press.

Garwe, E. C. (2013). Quality assurance challenges and opportunities faced by private Universities in Zimbabwe. Journal of Case Studies in Education, 5. http://aabri.com/jcse.html

Gillespie, N. A., Walsh, M., Winefield, A. H., Dua, J., \& Stough, C. (2001). Occupational stress in universities: Staff perceptions of the causes, consequences and moderators of stress. Work \& Stress, 15, 53-72. http://dx.doi.org/10.1080/02678370117944

Hakim, C., (1982). Secondary Analysis in Social Research, A guide to Data Sources and Methods with Examples. Boston: Allen and Unwin.

Hind, P., \& Doyle, C. (1996). A cross-cultural comparison of perceived occupational stress in academics in higher education. Paper presented at the XXVI International Congress of Psychology, Montreal, Canada.

Jackson, J. G., Fleming, H., Kamvounias, P., \& Varnham, S. (2009). Student grievances and discipline matters project. Final report to Australian learning and teaching council. Chancellery. 
Jain, K. (2013). Corruption: It's Silent Penetration into the Indian Education System. Journal of Education and Practice, 4(1), 30-36.

Kasozi, A. B. K. (2006). Regulating Transnational Higher Education in Uganda; consumers should be cautious. NCHE Kampala.

Katiliute, E., \& Kazlauskiene, I. (2010). The model of studies quality dimensions from student's perception. Economics and Management, 15, 580-586.

Kincheloe, J. L, \& McLaren, P. (2002). Rethinking critical theory and qualitative research. In: Y. Zou \& E. T. Trueba (eds.), Ethnography and schools: qualitative approaches to the study of education (pp. 87-138). Lanham, MD: Rowman \& Littlefield Publishers.

Kinman, G. (1998). Pressure Points: A Survey into the Causes and Consequences of Occupational Stress in UK Academic and Related Staff. London: Association of University Teachers.

Kinman, G. (2001). Pressure points: A review of research on stressors and strains in UK academics. Educational Psychology, 21, 473-492. http://dx.doi.org/10.1080/01443410120090849

Landon, E. L. (1980). Consumer satisfaction, dissatisfaction and complaining behavior as indicators of market performance. Advances in Consumer Research, 7(1), 186-191.

Latif, L. A., Ramli, B. P., \& Fard, Y. (2010). Improving Accessibility and Responsiveness in a Complaints Management System. E-Leader Singapore.

Lee, R. (2011). Everything Guide to Starting and Running a Restaurant: Secrets to a Successful Business! (2nd ed.) Adams Media Publishers.

Mamdani, M. (2007). Scholars in the Marketplace. CODESRIA, Senegal.

McNally, P. (2013). Qualitative research in medical education. In K Walsh (ed.), The Oxford textbook of medical education (pp. 638-647). Oxford: Oxford University Press.

Mogalakwe, M. (2006). The Use of Documentary Research Methods in Social Research. African Sociological Review, 10(1), 221-230.

Mohamedbhai, G. (2008). The Effects of Massification on Higher Education in Africa. Accra: Association of African Universities.

Narayan, L. (2014). Corruption in Education - Nature and Causes. International Journal of Research (IJR), 1(8), 2348-6848.

Noe, R. A., Hollenbeck, J. R., Gerhart, B., \& Wright, P. M. (2003). Human Resource Management. New York: Mc Graw Hill.

Olliffe, B., \& Stuhmcke, A. (2007). A National University Grievance Handler? Transporting the UK Office of the Independent Adjudicator for Higher Education (OIA) to Australia. Journal of Higher Education Policy and Management, 29(2), 203-215. http://dx.doi.org/10.1080/13600800701351777 
Plymire, J. (1991). Complaints as Opportunities. Journal of Services Marketing, 5, 61-5. http://dx.doi.org/10.1108/EUM0000000002528

Polit, D. F., \& Hungler, B. P. (1991). Nursing Research. Principles and Methods. Philadelphia: J. B. Lippincott Company.

Reader, T. W., Gillespie, A., \& Roberts, J. (2014). Patient complaints in healthcare systems: a systematic review and coding taxonomy. BMJ Quality and Safety, 23, 678-689. http://dx.doi.org/10.1136/bmjqs-2013-002437

Reichheld, F. F., \& Sasser, W. E. (1990). Zero Defections: Quality Comes to Services. Harvard Business Review, 68, 105-11.

Robson, C. (2011). Real world research (3rd ed.). Chichester: Wiley.

Rose, E. (2004). Employment Relations (2nd ed.). England: Prentice Hall.

Salamon, M. (2000). Industrial Relations: Theory and Practice (4th ed.). Great Britain: Prentice Hall.

Scott, J. (1990). A matter of record: Documentary sources in social research. Cambridge, UK: Polity Press.

Silverman, D. (1993). Interpreting Qualitative Data. Methods for Analysing Talk, Text and Interaction. London: Sage.

Tinto, V. (1993). Leaving college: Rethinking the causes and cures of student attrition (2nd ed.). Chicago: University of Chicago Press.

Tytherleigh, M. Y., Webb, C., Cooper, C. L., \& Ricketts, C. (2005). Occupational stress in UK higher education institutions: A comparative study of all staff categories. Higher Education Research \& Development, 1, 41-61. http://dx.doi.org/10.1080/0729436052000318569

Walsh, K. (2014). Documentary research and evaluation in medical education. Journal of Educational Evaluation for Health Professions 11, http://dx.doi.org/10.3352/jeehp.2014.11.18

Yin, R. K. (1994). Case study research: design and methods. Thousand Oaks: Sage.

Yin, R. K. (2003). Applications of case study research (applied social research methods). Series, 4th. Thousand Oaks: Sage Publications.

Zimbabwe Council for Higher Education (ZIMCHE). (2013). Annual Report. Harare: ZIMCHE.

\section{Copyright Disclaimer}

Copyright reserved by the authors.

This article is an open-access article distributed under the terms and conditions of the Creative Commons Attribution license (http://creativecommons.org/licenses/by/3.0/). 